\title{
Faking Translation in Hallstatt: A Visit to Hallstatt Revisited I
}

\author{
Susan Ingram and Markus Reisenleitner \\ York University
}

Norbert Artner's Hallstatt Revisited I is a series of ten large colour photographs that were taken in Huizhou, a city of 4.6 million located in the booming industrial heartland of China's southern Guangdong province on the South China Sea, for display in Hallstatt, the über-picturesque tourist village in Austria's Salqkammergut region with a population (as of 2013) of 795 that in 1997 was granted UNESCO World Heritage site status. One need not look too far for Artner's motivation for the series: in 2012, a copycat version of Hallstatt, "conceived by a Chinese mining tycoon and backed by Minmetals Land Inc.” (Zeveloff), opened in Huizhou, one of several European sites to receive the treatment Bianca Bosker, in Original Copies: Architectural Mimicry in Contemporary China, calls the creation of a "simulacrascape" (4). Unlike the documentary film London-based artists Sebastian Acker and Phil Thompson are in the process of making about Chinese "duplitecture" in "copy towns," the Austrian Artner designed his project at a literally grassroots level, taking photographs of sites in Hallstatt 2 with the express intent of displaying them in particular locations in the original, which has in the meantime become known as Hallstatt 1. In what follows we contextualize Artner's photographs with our own, ${ }^{2}$ with the aim of opening up an analytical mise en abyme into the intriguing experiments that, as Ackbar Abbas indicated in "Faking Globalization," are set to become a hallmark of the urban Asian experience in the $21^{\text {st }}$ century (243). Mobilizing Abbas's juxtaposition of Deleuze's “any-space-whatever" and Mario Gandelsonas's "X-urbanism," we see how Artner's series represents a kind of " $21^{\text {st }}$-century urbanism with Chinese characteristics" and makes clear the need to distinguish among different forms of copying. (Figures 1, 2, 3)

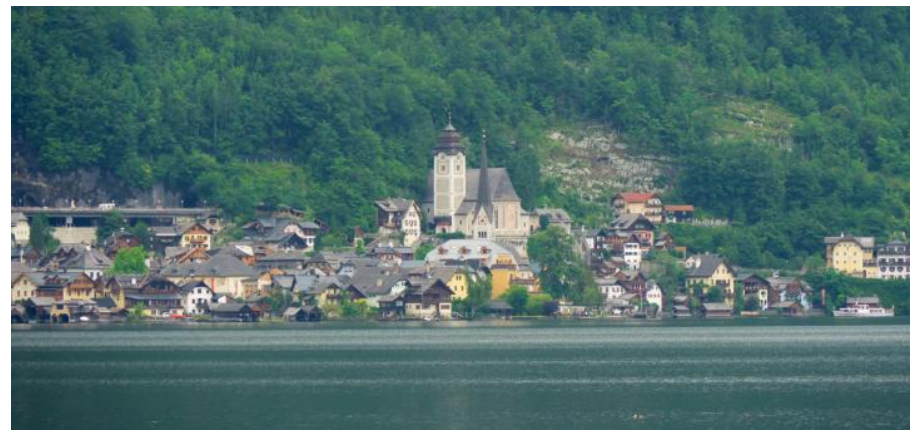

Figure 1

1 Cf. "A Pair of Artists" and "Hallstatt, China."

2 All of the photographs that accompany this text are our own and were mostly taken the day after Artner's street exhibition opened on July 20, 2014. 
TranscUlturAl, vol. 6.1 (2014), 43-52.

http://ejournals.library.ualberta.ca/index.php/TC

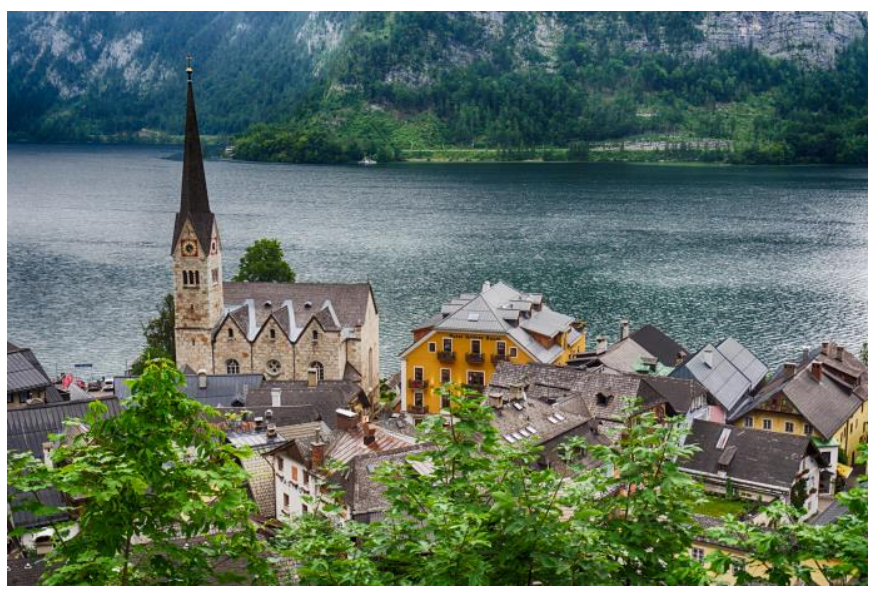

Figure 2

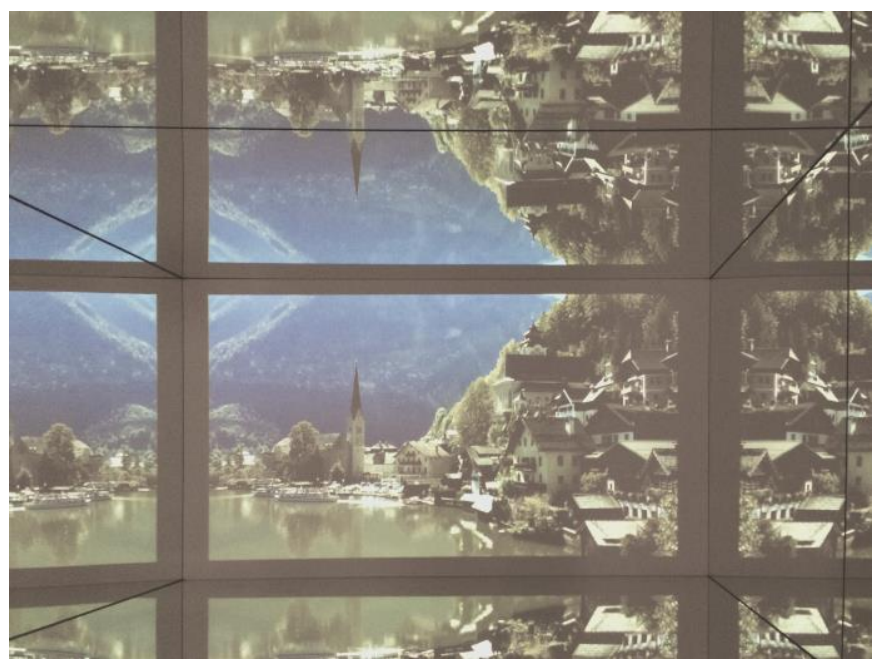

Figure 3

Abbas's eloquently economic summary of Deleuze reminds us that the concept of "anyspace-whatever" was developed as part of Deleuze's discussion of three types of movement image: the affection image, the action image and the perception image, associated with the close up, the medium shot, and the long shot, respectively (244). Unlike action images, which focus on the duration of the image, and perception images, which focus on what is seen, the affection image focuses on the expression of emotions, which, as Abbas notes:

helps not only to underline the important relation between affectivity and space but also to differentiate between space and place, affectivity and emotion, along the following lines: as 'space' refers us to places we do not yet understand, or no longer understand, so affect refers us to emotions we do not yet have, or no longer have a name for. In both cases, some kind of shift has occurred. As Deleuze explains it, any-space-whatever is the polar opposite of an actualized 'state of things,' which is always framed in terms of spatiotemporal-psychic coordinates that we tacitly understand. (244-5, italics in original) 
The shift that has taken place with the construction/production of Hallstatt, China transforms Hallstatt, Austria into something one can no longer tacitly understand. It feels weird to walk around a place that one knows has been copied, and this feeling is intensified by the knowledge that one is unlikely to ever visit the copy, as well as by the strong presence of Asian tourists in the original, which has risen from fewer than 50 in 2005 to the point that "now thousands fly to the Austrian town every year, according to officials from the Austrian delegation in China" (Wu). (Figures 4, 5, 6, $7,8)$

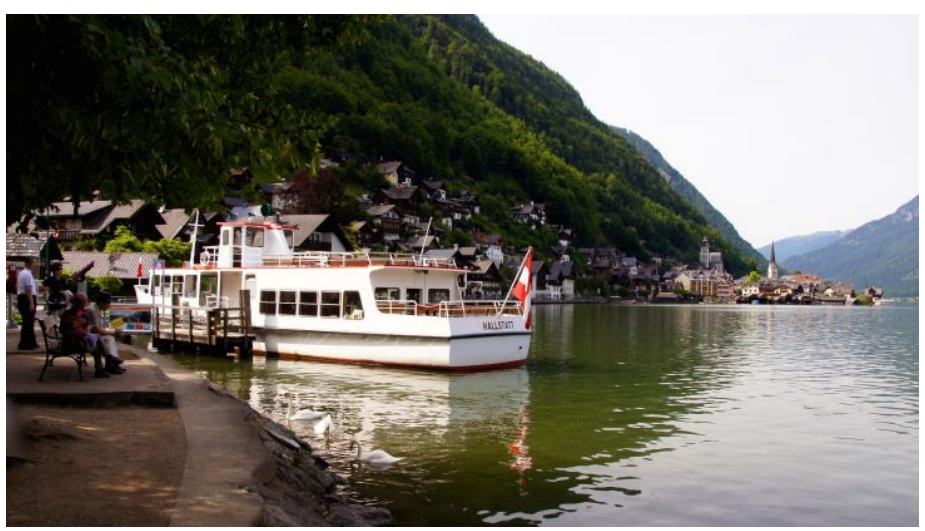

Figure 4

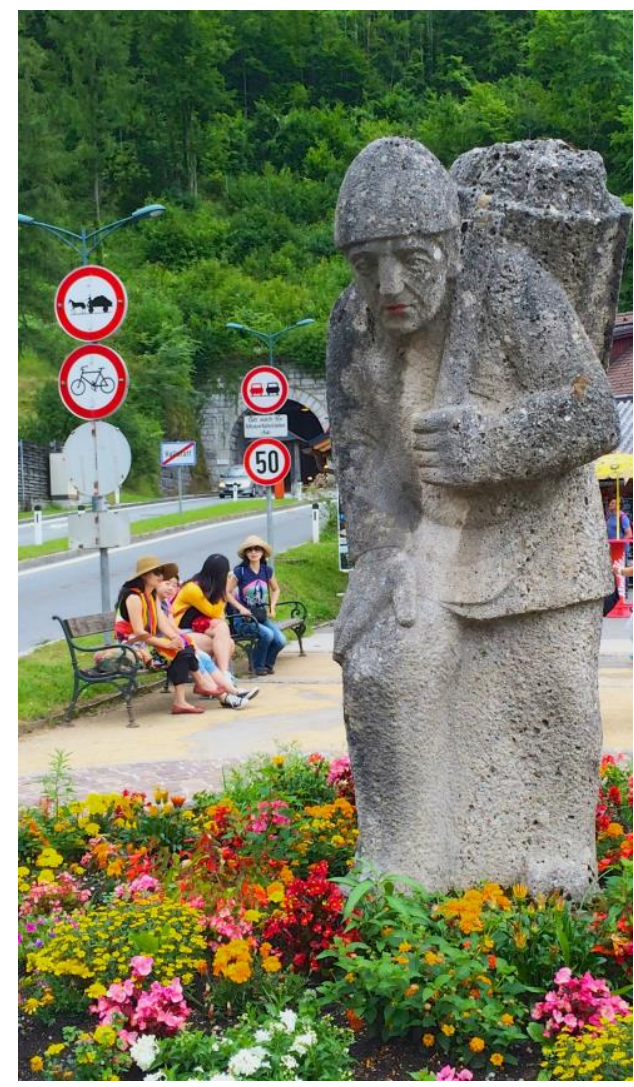

Figure 5 
TranscUlturAl, vol. 6.1 (2014), 43-52.

http://ejournals.library.ualberta.ca/index.php/TC

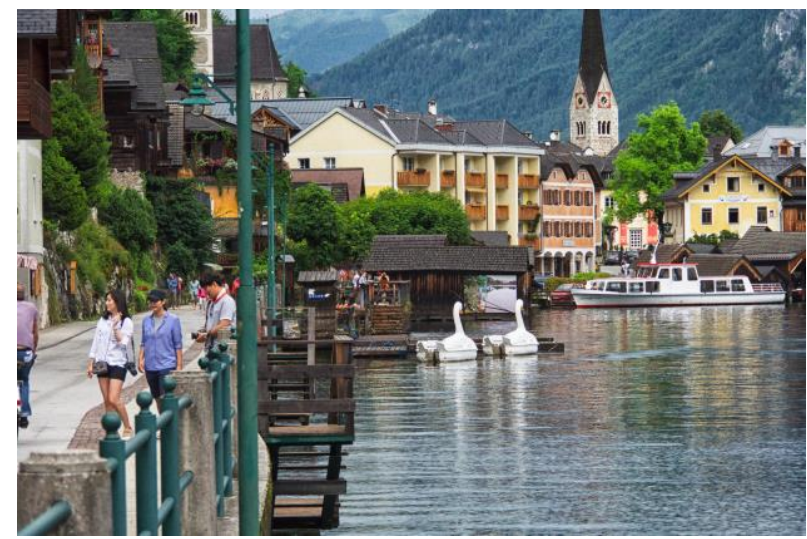

Figure 6

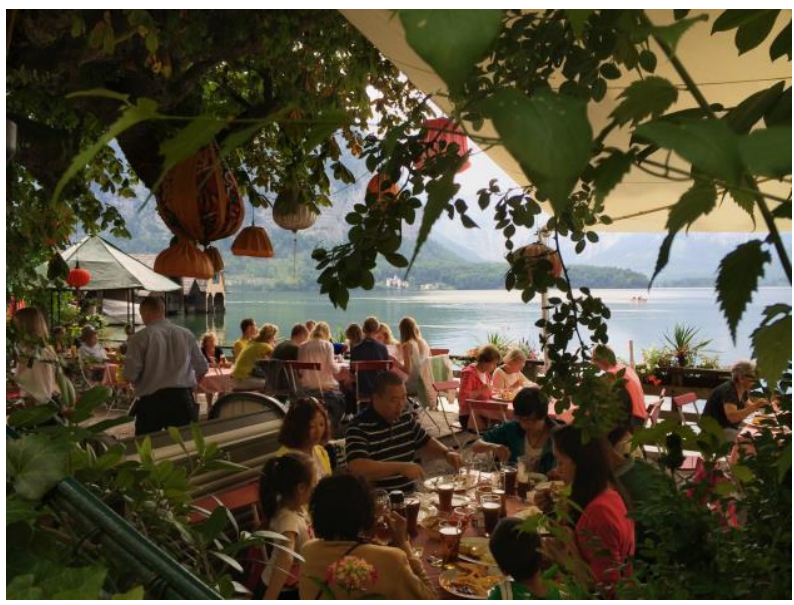

Figure 7

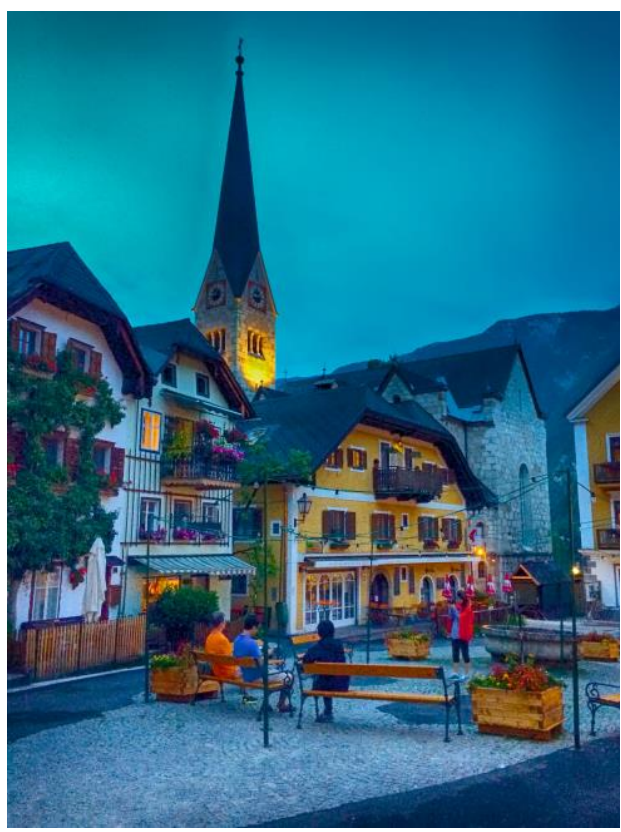

Figure 8 
Even Chinese visitors are unlikely to have visited the copy. Artner notes that one mainly finds real-estate agents and wedding parties there, something confirmed by Acker's description that "Chinese visitors would walk by in small clusters, snapping pictures of the curious English tourists surveying the Alpine ornament that graces the facades of buildings" ("A Pair of Artists"), just as Caucasian visitors snap pictures of the curious Asian tourists photographing the Alpine surroundings in the original. What one will not find in the copy are Austrian locals, who are known to be very forthcoming with directions (Figure 9).

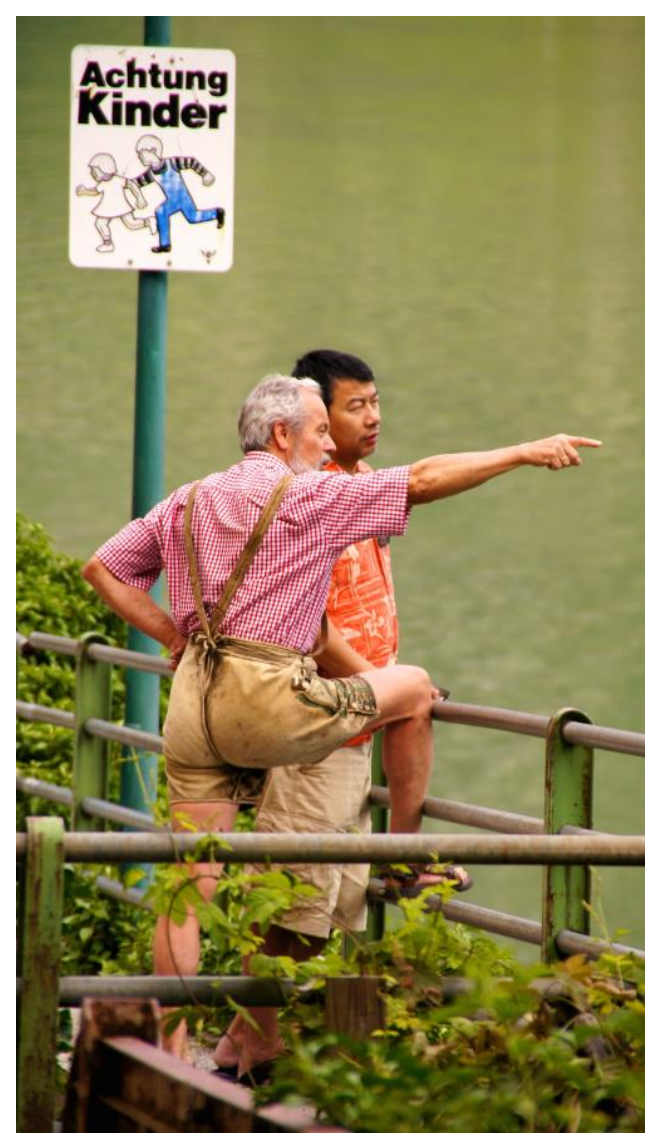

Figure 9

Hallstatt 2, on the other hand, is a typical Chinese simulacrascape in that it is "devoid of urban life, their streets mostly filled with maintenance workers or real estate agents" (ibid). In Acker's assessment "on the whole, the towns felt very much out of time" (ibid), precisely the affective quality that Artner's photographs have been positioned to engender. The series of 10 photographs work like a series of matrioshka dolls. They are bracketed at each end of the village by the two that are hardest to find, as they are in carparks (Figures 10 and 11), 
TranscUlturAl, vol. 6.1 (2014), 43-52.

http://ejournals.library.ualberta.ca/index.php/TC

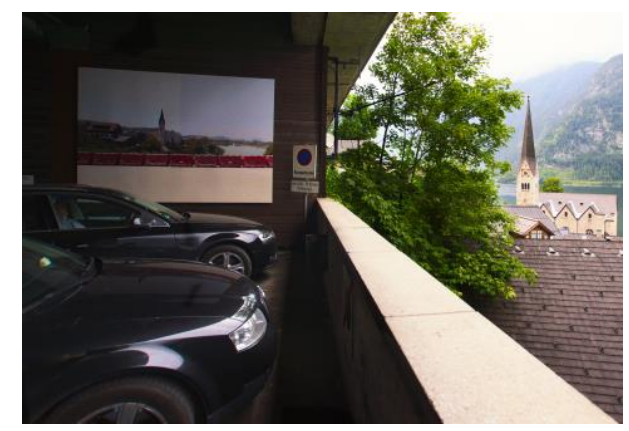

Figure 10

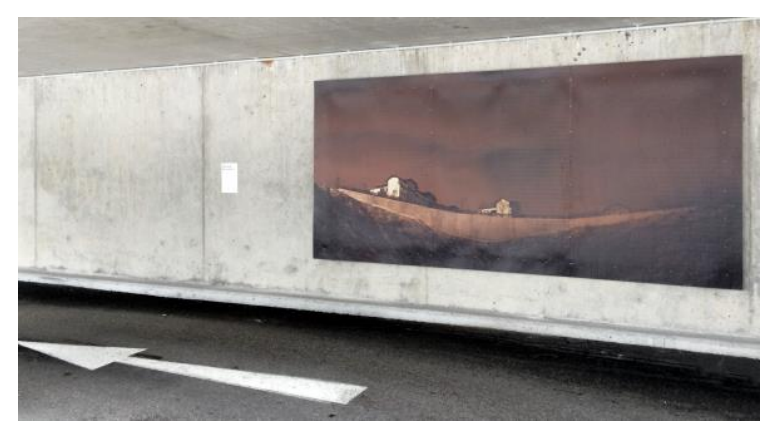

Figure 11

within which are two barnlike structures in two of the outlying housing areas (Figures 12, 13);

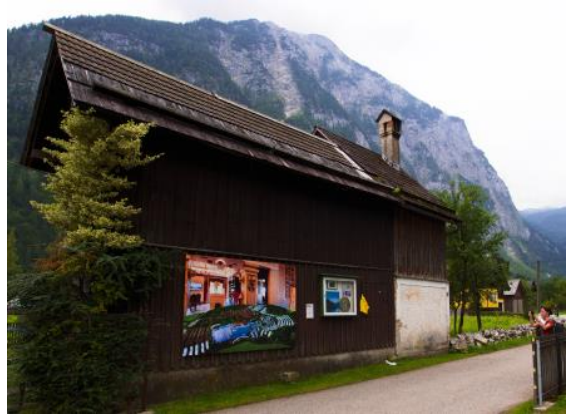

Figure 12

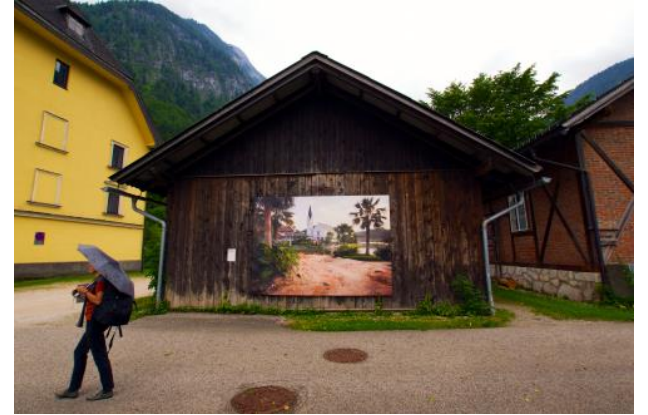

Figure 13

one along the lake is matched with one on the central grocery store, both sites of sustenance (Figures 14, 15);

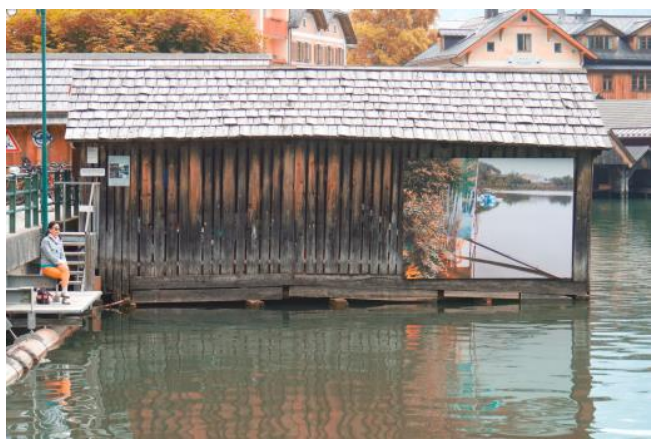

Figure 14

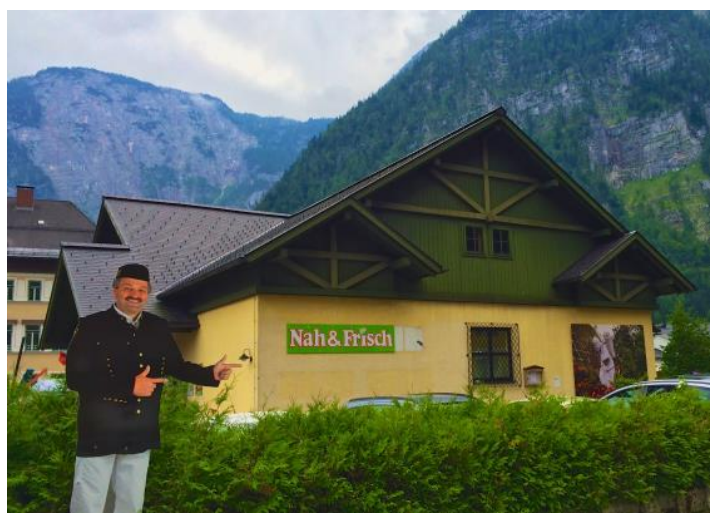

Figure 15

two images are in the grounds of the Hallstatt museum (Figures 16, 17); 


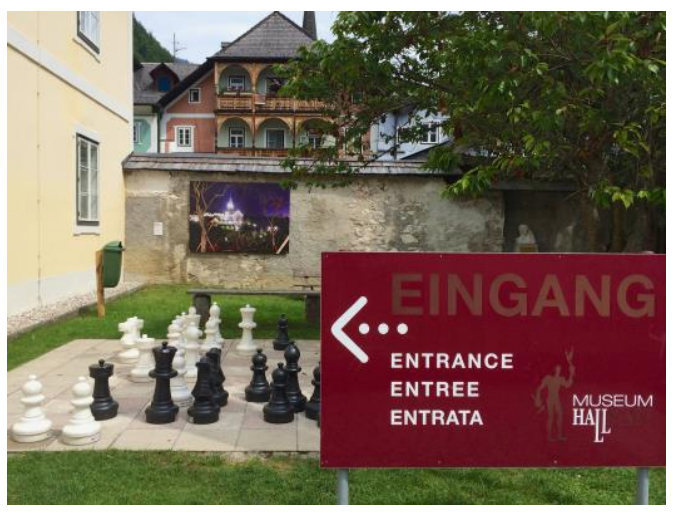

Figure 16

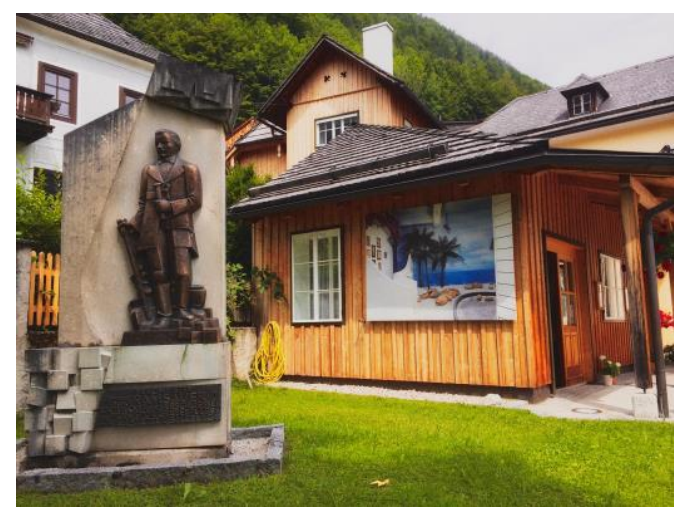

Figure 17

while the centerpiece is the most photographed spot in town (Figure 18).

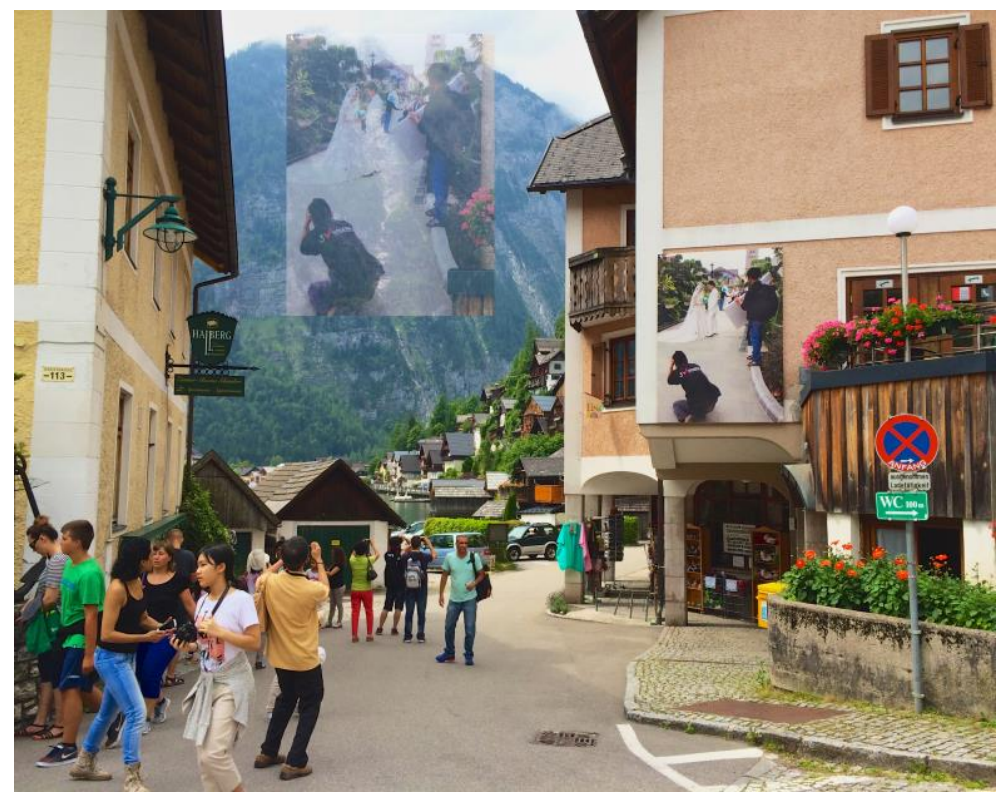

Figure 18

The question of framing and deframing plays a key role in Gandelsonas's typology of mutating urban forms:

The city of skyscrapers created a new urban structure made up of three concentric rings, with the core business district at the center, surrounded by a second ring of poor neighborhoods and factories, outside of which, in a third ring, lie the suburbs where the middle classes live. The suburbs' development into the suburban city is made possible by, among other things, the motorcar and television; one extends the suburban house to the city, the other brings the city to the house. (Abbas 247)

The next stage, X-urbanism, takes place when centre and periphery, core and suburb, start to blur, with housing moving into the core and offices, shopping and entertainment plazas moving into the 
suburbs. X-urbia therefore "does not supplement the suburban city, but supplants it, changing it from the inside out" (ibid). While "any-space-whatever" can be considered a form of modern fragmentation, with the fragment "a form of resistance to homogenization and assimilation into a whole," the X-urban functions as a postmodern fractal, "not the contestation of the whole, but rather the replication, on a smaller scale, of the whole" (Abbas 248).

Replication is a manifestation of the Chinese practice of shanzhai, which is usually translated as piracy, copying, counterfeiting, or faking, all terms with pejorative connotations for a Western tradition that values originality, individuality, autonomy, sovereignty, and everything else implied by what Foucault termed "the author function." Rather than simply condemn the fake, Acker and Thompson conclude from their project that one should recognize that "Copying is nothing new to the study and production of buildings and cities, and it's only getting a lot easier. As Ai Weiwei put it to them when they showed up at his front door: 'Now architecture speaks the language of computers-which have three buttons: copy, paste, delete" ("A Pair of Artists"). That echoes Abbas' encouragement to approach fakes as a symptom of the current global dis/ reorder: "Insofar as the fake points to unresolved problems in the world today, it should be analyzed, not dismissed" (252).

The aesthetic status of Artner's Hallstatt Revisited I vis-à-vis its object makes clear that it is the materiality of the Chinese village that is the crux of the matter of its "fakeness," and not the fact of the Austrian village's reproduction per se. Rather, the photogenic qualities of the Austrian Hallstatt suggest that it was destined to be, and has been, reproduced, re-imaged, and re-imagined (Figure 19);

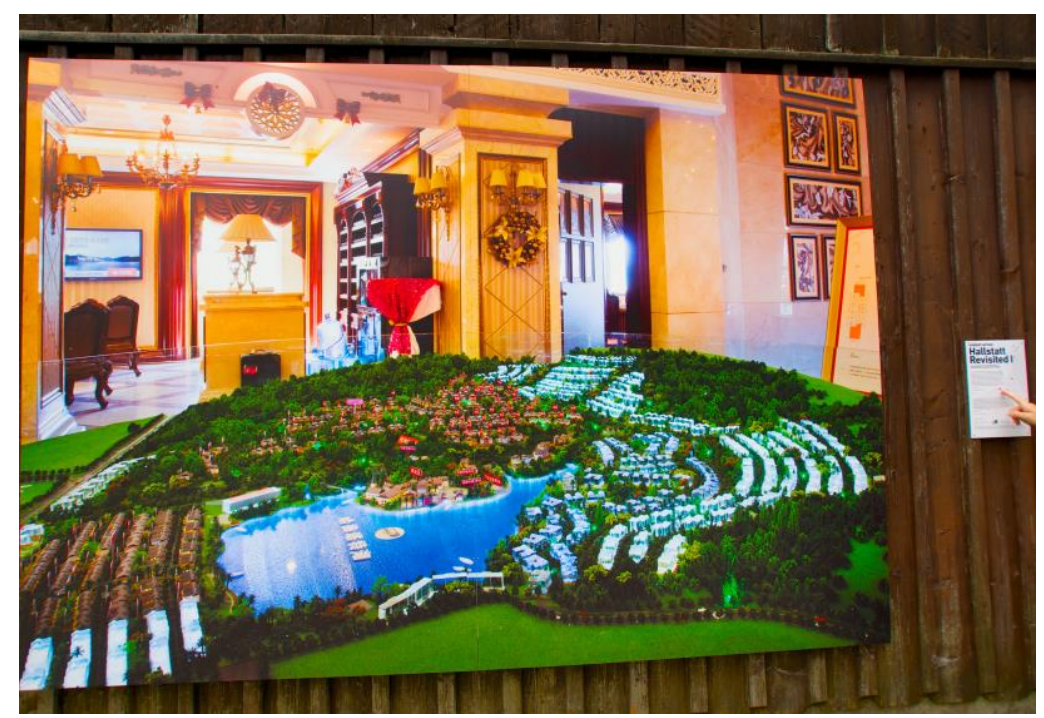

Figure 19

the Hallstatt museum has on display a long tradition of painterly, photographic and material depictions of the village (Figure 20). 
TranscUlturAl, vol. 6.1 (2014), 43-52.

http://ejournals.library.ualberta.ca/index.php/TC

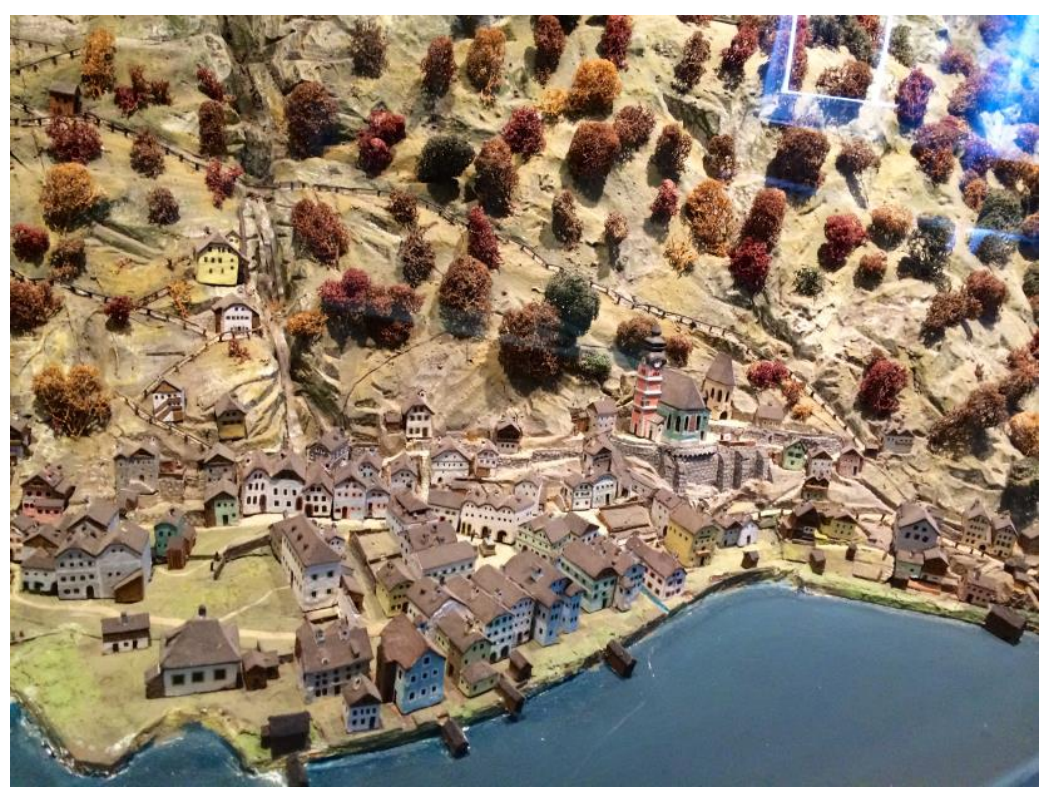

Figure 20

The Chinese village is problematic only because it did something artistic reproductions are unable to do, namely, change the ontological status of the original, from Hallstatt to Hallstatt 1.

The creation of Hallstatt 2 invites a series like Artner's, a reinsertion of the copy into the original in spaces that the copy has opened up because it is a very particular kind of copy, namely, to speak with Abbas, a (postmodern) replication rather than a (modern) reproduction. This distinction calls for another turn in translation theory, one capable of distinguishing between these forms of copying. 
TranscUlturAl, vol. 6.1 (2014), 43-52.

http://ejournals.library.ualberta.ca/index.php/TC

\section{REFERENCES}

“A Pair Of Artists Reveal China's Counterfeit Cities.” http://www.fastcodesign.com/1672620/apair-of-artists-reveal-chinas-counterfeit-cities, accessed 10 August 2014.

Abbas, Ackbar. "Faking Globalization." Other Cities, Other Worlds: Urban Imaginaries in a Globalizing Age. Ed. Andreas Huyssen. Durham, NC: Duke University Press, 2008. 243-64.

Bosker, Bianca. Original Copies: Architectural Mimicry in Contemporary China. Honolulu: University of Hawaii Press, 2013.

"Hallstatt, China." http://ackerthompson.tumblr.com, accessed 10 August 2014.

Wu, Venus. "Made in China: An Austrian Village." Reuters online, 4 June 2012. http://www.reuters.com/article/2012/06/04/uk-china-austria-idUSLNE85301M20120604, accessed 10 August 2014.

Zeveloff, Julie. “China Unveils A Knockoff Version Of An Entire Austrian Village.” Business Insider, 4 June 2012, http://www.businessinsider.com/china-has-built-a-copycat-version-of-anentire-austrian-village-2012-6?op=1\#ixzz39994Og4o, accessed 10 August 2014. 